\title{
Ten Principles for Biocultural Conservation at the Southern Tip of the Americas: the Approach of the Omora Ethnobotanical Park
}

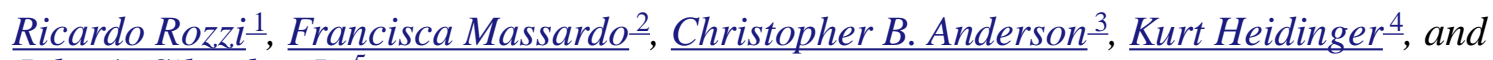 \\ John A. Silander, Jr.
}

\begin{abstract}
Although there is general agreement among conservation practitioners about the need for (1) social involvement on the part of scientists; (2) interdisciplinary approaches; (3) working on local, regional, and global levels; and (4) implementing international agreements on biodiversity and environmental protection, a major challenge we face in conservation today is how to integrate and implement these multiple dimensions. Few researchers have actually offered hands-on examples for showing in practical terms how such integration can be accomplished. To address this challenge we present an innovative case study: the Omora Ethnobotanical Park, a long-term biocultural conservation initiative at the southern extreme of the Americas. Located near Puerto Williams (55 $\mathrm{S}$ ), Cape Horn Archipelago region, Chile, the Omora Park is a public-private reserve that provides material and conceptual foundations for three complementary conservation actions: (1) interdisciplinary scientific research; (2) informal and formal education, i.e., school, university, and training courses; and (3) biocultural conservation. The latter entails an actual reserve that protects biodiversity and the water quality of Puerto Williams' watershed, as well as programs on Yahgan traditional ecological knowledge and interdisciplinary activities, such as "field environmental ethics" and ecotourism, carried out in the reserve. Being at the "end of the world," and within one of the most remote and pristine ecoregions on the planet, Omora Park offers a "bio-cultural treasure." At the same time, its geographical and technological isolation presents a challenge for implementing and sustaining conservation actions. To achieve the general conservation goals, we have defined 10 principles that have guided the actions of Omora: (1) interinstitutional cooperation, (2) a participatory approach, (3) an interdisciplinary approach, (4) networking and international cooperation, (5) communication through the media, (6) identification of a flagship species, (7) outdoor formal and informal education, (8) economic sustainability and ecotourism, (9) administrative sustainability, and (10) research and conceptual sustainability for conservation. These principles have been effective for establishing the long-term Omora initiative, as well as involving multiple actors, disciplines, and scales. Upon these foundations, the Omora initiative has extended its local goals to the regional level through a successful 5-yr process in cooperation with the Chilean government to create the Cape Horn Biosphere Reserve, designated by UNESCO in June 2005, with the goal of establishing a long-term institutionalpolitical framework that promotes social well-being and biocultural conservation at the southernmost tip of the Americas.
\end{abstract}

Key Words: biocultural conservation; biosphere reserve; Cape Horn; Chile; environmental education; environmental ethics; flagship species; interdisciplinary; interinstitutional; sustainability; traditional ecological knowledge; Yahgan.

\footnotetext{
${ }^{1}$ Department of Philosphy and Religion Studies, University of North Texas, ${ }^{2}$ Facultad de Ciencias, Universidad de Magallanes, ${ }^{3}$ Institute of Ecology, University of Georgia, ${ }^{4}$ Omora Sub-Antarctic Research Alliance, ${ }^{5}$ Department of Ecology and Evolutionary Biology, University of Connecticut
} 


\section{INTRODUCTION}

During the 1980s, conservation biologists successfully characterized the alarming losses of biodiversity and raised public awareness about the multiple human causes and problems associated with these losses (Primack et al. 2001). In the 1990s, it was recognized that greater integration between ecological and social dimensions was required to achieve conservation goals (Pandey and Wells 1997, Rozzi and Feinsinger 2001). Also, ecological societies and ecologists called for greater involvement of scientists with environmental decision makers and educators (e.g., Lubchenco et al. 1991, Vitousek 1994). The Ecological Society of America's Sustainable Biosphere Initiative (ESA-SBI), encouraged ecologists to become involved in environmental education and decision making, and the ESA-SBI provided a stimulus to overcome narrow specialization and the divide between basic and applied science, not only in the United States but abroad as well (Huntley et al. 1991, Rozzi et al. 1998, 2000). Additionally, a new level of political involvement and awareness regarding losses of biodiversity, environmental degradation, and their connections with social problems was achieved through new international agreements, e.g., Convention on Biological Diversity, Kyoto Protocol.

Since 2000, though, a central challenge faced by conservation biology is how to effectively implement international environmental conventions and models while integrating multiple ecological and social dimensions at local, regional, and global levels (Holling 2004, Jax and Rozzi 2004). Today, there is a general consensus among conservation practitioners regarding the need for: (1) social involvement by scientists (Bradshaw and Beckoff 2001); (2) interdisciplinary approaches that integrate human and biological factors (Gunderson et al. 1995); (3) a focus on local, regional, and global levels (Primack et al. 2001); and (4) the establishment of international agreements on biodiversity and environmental protection (UNESCO 2000). Despite the general agreement on these goals, most conservation biology research and scholarly articles continue to have a traditional, narrow disciplinary focus (Noss 1999), educational curricula have not shown sufficient innovation (Clark 2001), and there is a shortage of hands-on examples or demonstrative case studies (Heemskerk et al. 2003).
This article presents a case study of a long-term biological and cultural conservation initiative at the southern extreme of the Americas, offering insights at two levels. First, we characterize the process of creation of the Omora Ethnobotanical Park (OEP) and the Cape Horn Biosphere Reserve, emphasizing the integration of social, cultural, and ecological dimensions required by this conservation initiative. Given its isolated character, low anthropogenic impact, and small population (2500), the vast Cape Horn Archipelago region $\left(55^{\circ} \mathrm{S}\right)$ offers an ideal venue for a proactive conservation initiative, especially now that the area is confronting increasing pressures of development, tourism, aquaculture, and the exploitation of natural resources.

Here, we lay out a set of 10 interrelated principles for implementing biocultural conservation. These principles are nested at local, regional, national, and international scales, and involve multiple institutions, actors, and disciplines. This set of principles had both applied and theoretical value for the Omora initiative. They contributed to policy making and regional planning, and they integrate across disciplines that have remained largely disconnected within the field of conservation: the sciences and humanities (Oelschlaeger and Rozzi 1998, Primack et al. 2001), biological and cultural diversity (Rozzi et al. 2003a), and theory and practice (Rozzi 1999, 2003a).

We first introduce the unique biological and cultural attributes of the Cape Horn region and the conservation challenges that this region faces today. We then provide an overview of OEP's origins and its strategy to turn theory into practice, describing its 10 principles for biocultural conservation. In the final section, we briefly discuss some of the main findings, and challenges that the Omora initiative had to overcome to achieve sustainable conservation.

\section{CAPE HORN: A UNIQUE REGION OF THE WORLD'S BIOLOGICAL AND CULTURAL DIVERSITY}

The Cape Horn Archipelago (CHA) comprises an extensive area of the subantarctic, or subpolar, Magellanic evergreen rainforest that extends north to the Penas Gulf (Fig. 1). This area constitutes one of the Earth's 37 most pristine ecoregions (Mittermeier et al. 2002). CHA also hosts the 
Fig. 1. Location of the Omora Park on Navarino Island south of Tierra del Fuego and the Beagle Channel, in the region of Cape Horn, at the southern extreme of the American Continent. Dark green depicts the subantarctic or subpolar Magallanic evergreen rainforest ecoregion, which runs along the Chilean Pacific Coast from Golfo de Penas $\left(48^{\circ} \mathrm{S}\right)$ to Cape Horn $\left(56^{\circ} \mathrm{S}\right)$. This ecoregion has been identified as one of the 37 most pristine areas in the world. The criteria to identify the most pristine ecoregions or wilderness areas in the world were: (1) $70 \%$ or more of their original vegetation intact, (2) cover at least $10,000 \mathrm{~km}^{2}$, and (3) have fewer than five people $/ \mathrm{km}^{2}$ (Mittermeier et al. 2002).

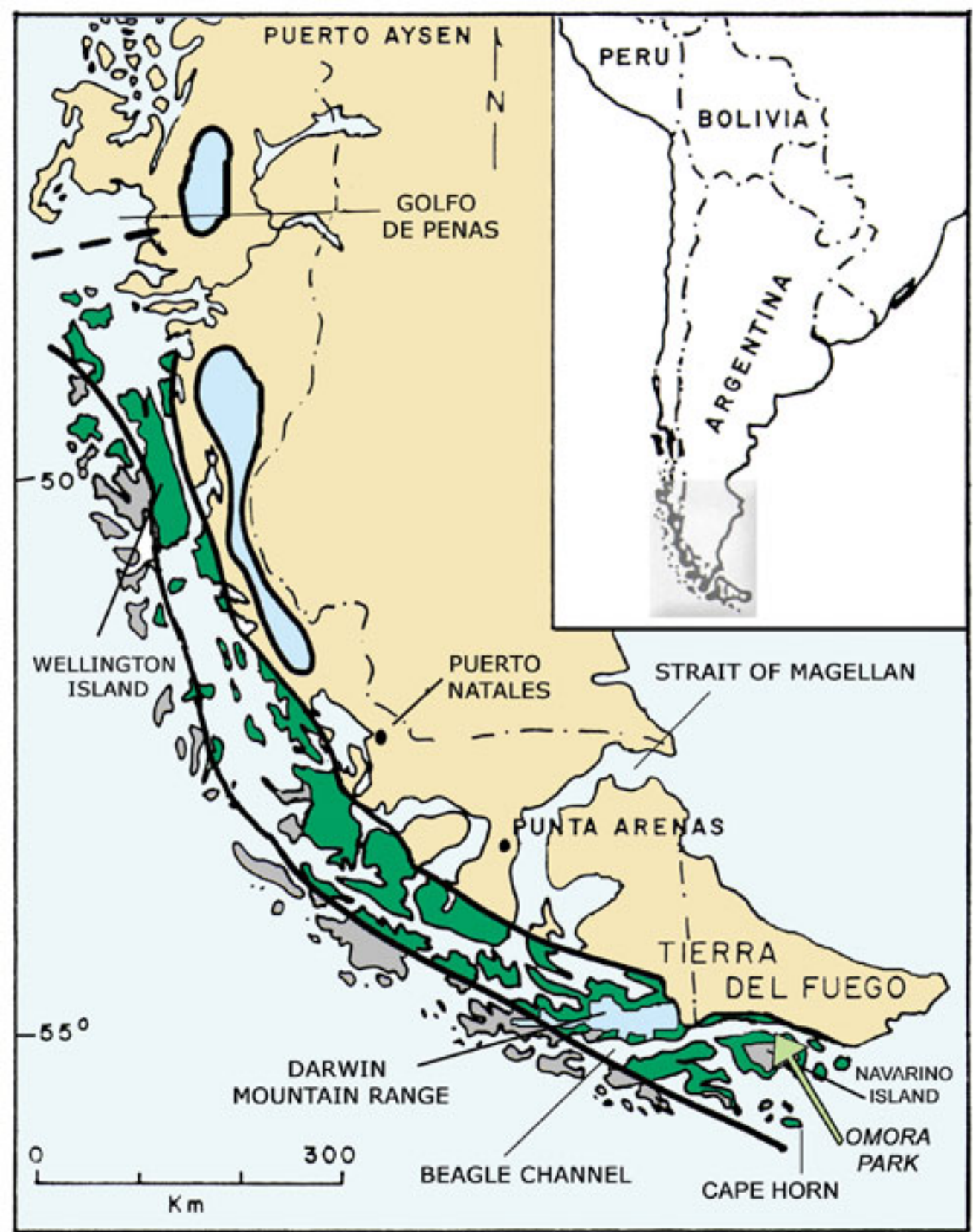


Fig. 2. The Omora Park extends $920 \mathrm{~m}$ from the Beagle Channel to the summit of Robalo Mountain. This altitudinal gradient includes the characteristic habitat types of the Cape Horn region. From the shoreline upwards these habitats are: evergreen forests dominated by Nothofagus betuloides (Nb); mixed evergreen-deciduous forests dominated by $N$. betuloides and $N$. pumilio (Np); deciduous forests dominated by $N$. pumilio and $N$. $\operatorname{antarctica}(\mathrm{Na})$; alpine tundra dominated at lower levels by cushion plants, e.g., Bolax gummifera (Bg); and at upper levels by lichens (Neuropogon sp. (Nsp). For an illustration of these habitat types see Appendix 1.

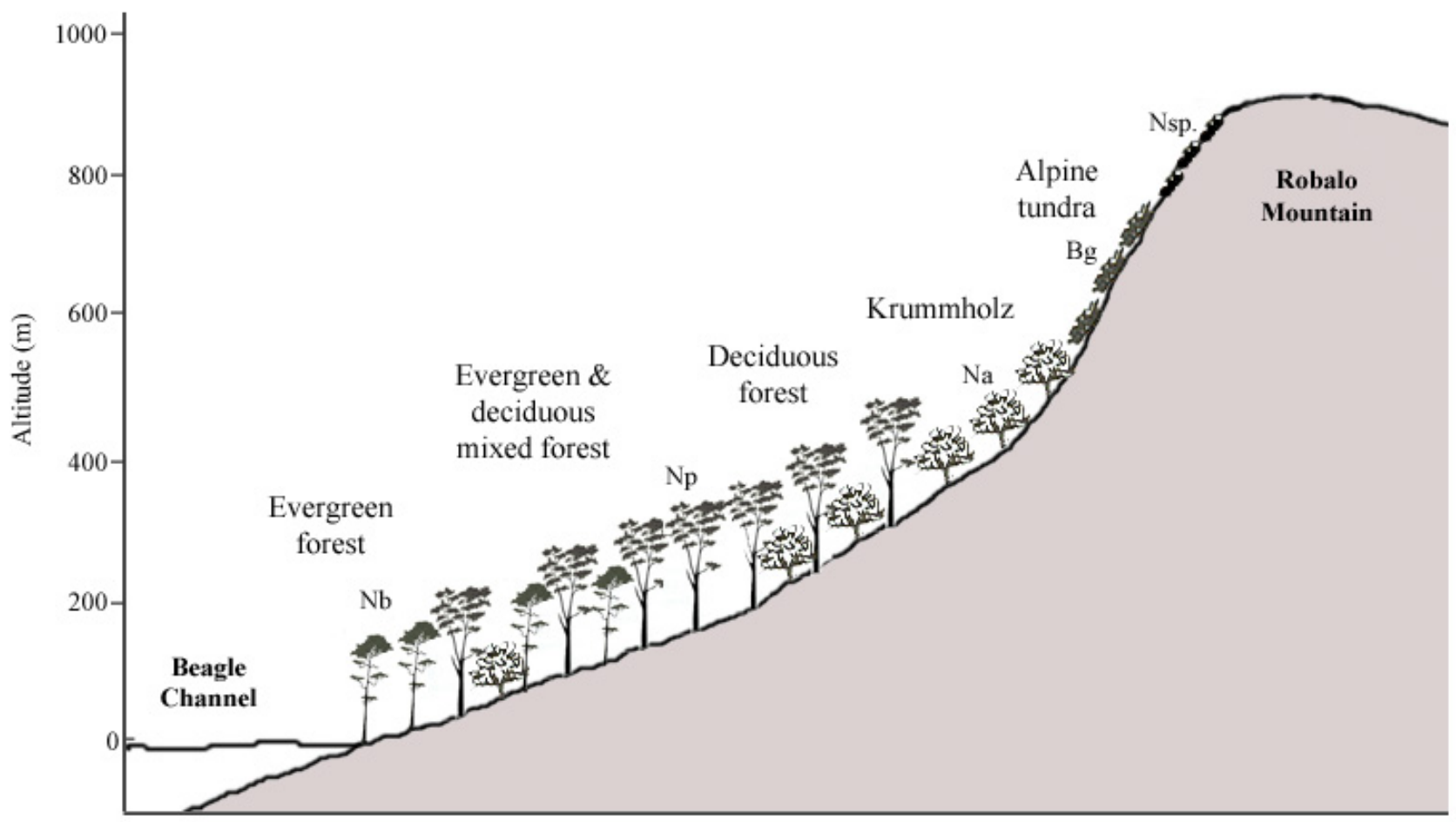

world's southernmost forest ecosystems (Silander 2000) and a diverse mosaic of habitat types (Appendix 1), which have been protected from extensive human impact by their geographic isolation and the presence of a Chilean Navy reserve south of Tierra del Fuego.

CHA also has high cultural value. It encompasses the ancestral territory of the Yahgans, the world's southernmost ethnic group (McEwan et al. 1997). Nomadic hunters, fishers, and gatherers, the Yahgans canoed the channels of the subantarctic archipelago region south of Tierra del Fuego, leaving behind a remarkable Amerindian archaeological and cultural legacy (Gusinde 1961). Hundreds of shell middens found along the coasts of Navarino and other islands in the archipelago testify to their material culture, and represent one of the highest concentrations of archaeological sites in the world (Rivas et al. 1999). Today, only 100 Yahgan descendants remain, and they are severely acculturated (Rozzi 2005). The Yahgan's complex cosmology and ecological knowledge survive today in their artisan practices, as well as in ethnographic records (Rozzi et al. 2003a,b, Alvarez et al. 2004). CHA, furthermore, occupies a central place in the history of science, as Charles Darwin (1839) spent a significant proportion of his time during The 
Fig. 3. Three main domains of action of the Omora Ethnobotanical Park initiative: (1) interdisciplinary scientific research; (2) formal and informal education, i.e., school, university, and training courses; and (3) biocultural conservation linked with local sustainable development. The triangle of these interrelated domains represents a local adaptation of the Ecological Society of America's Sustainable Biosphere Initiative (ESA-SBI, Luchenco et al. 1991a). At the center, Omora's logo illustrates the goals of integrating biological and cultural conservation through the image of the firecrown hummingbird (Sephanoides sephaniodes), or omora in the Yahgan language, visiting its preferred flower the coicopihue (Philesia magellainica), and carrying a harpoon, one of the main hunting tool used by the Yahgan indigenous people.

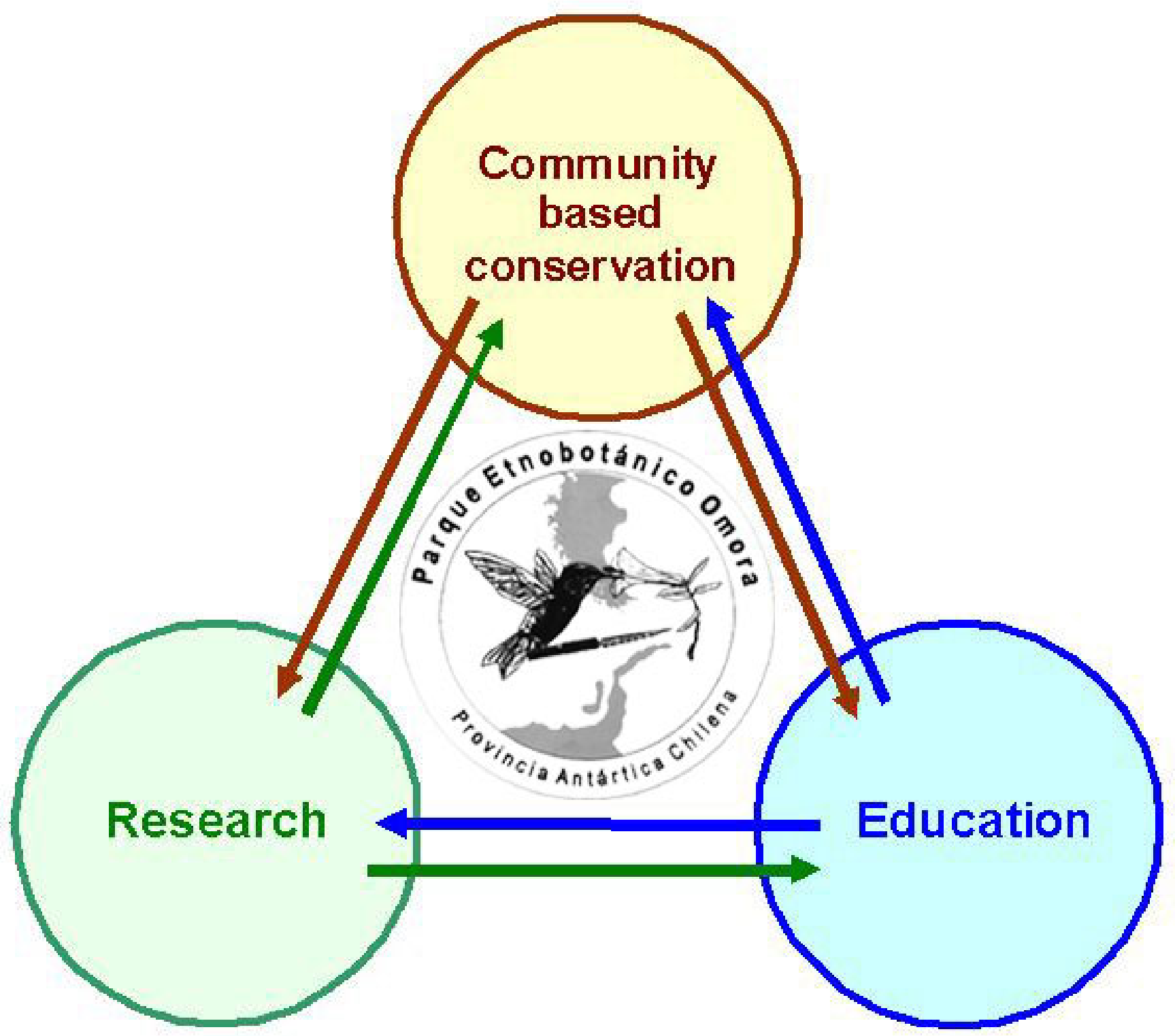


Table 1. Ten principles guide the actions of Omora Park to implement biocultural conservation at the southern extreme of the Americas. All principles interact simultaneously and have multiple functions; however, they can be grouped under three main subject areas and practices that enable Omora to put these concepts into action.

\begin{tabular}{l}
\hline \hline Principle \\
(1) Interinstitutional collaboration \\
(2) Participatory approach \\
(3) Interdisciplinary biocultural approach \\
(4) Networking and international \\
cooperation
\end{tabular}

(5) Communication through the media

Outreach of biocultural conservation practices and results

Maintaining diverse participants in the project

\section{Practice}

Omora's participatory approach, involving crossscale interplay of institutions with both horizontal and vertical linkages
Involving the community in the Omora initiative, reaching out to local, national, and international levels; biocultural integration of sciences and humanities

(6) Identification of a flagship species

(7) Integration of curriculum and intercultural education in the outdoors

(8) Economic sustainability

Sustainable socioecological A three-dimensional approach to achieve systems sustainability at the level of the Omora Park, as well as the level of the Cape Horn region, based on a biocultural vision of place

(9) Social and administrative sustainability

(10) Research and conceptual sustainability

Voyage of the Beagle in the area, and his encounters with the Yahgans were crucial for the development of his theory of human evolution (Rozzi 1999).

Today, the remote $\mathrm{CHA}$ region of fjords, mountains, glaciers, sea, and intact natural landscapes represents a cultural and natural heritage for all humanity. However, this region faces major conservation challenges because the two "protective barriers" that have helped to preserve its pristine character are now being eroded: (1) Its remoteness is being eliminated by rapid transportation and infrastructure development and (2) Vast areas formerly protected as a military reserve are being reduced (Rozzi et al. 2003c). It is against this backdrop of rapid social and economic transformation that a group of scientists, artists, philosophers, and other professionals, both Chilean and foreign, initiated a program of biocultural conservation in 1999 that led to the creation of the Omora Ethnobotanical Park. 
Table 2. Core institutions involved in the Omora initiative at local (L) regional (R), national (N), and/or international (I) levels. The main functions of each institution are pointed out for each scale.

\begin{tabular}{|c|c|c|}
\hline Institution & $\begin{array}{l}\text { Level(s) of } \\
\text { action }\end{array}$ & Main Function \\
\hline Omora NGO & All & $\begin{array}{l}\text { Responsible for the creation of the Omora Park and consistency of the } \\
\text { initiative; legal holder of the Park's land concession; and owner of the land } \\
\text { for the future Omora Center Biocultural Conservation and Environmental } \\
\text { Philosophy. }\end{array}$ \\
\hline University of Magallanes & All & $\begin{array}{l}\text { Co-responsible party for the overall initiative; co-holder of land concession; } \\
\text { established a branch of the university in Puerto Williams. }\end{array}$ \\
\hline \multirow[t]{2}{*}{ Chilean Land Ministry } & $\mathrm{N}$ & Oversees and grants the free concession of the land for the Omora Park. \\
\hline & $\mathrm{R}$ & $\begin{array}{l}\text { Monitors the fulfillment of the objectives in the renewable } 50 \text {-yr concession } \\
\text { contract. }\end{array}$ \\
\hline $\begin{array}{l}\text { Indigenous Yahgan } \\
\text { Community }\end{array}$ & $\mathrm{L}$ & $\begin{array}{l}\text { Co-designer and co-implementer of the Omora park; collaborative research } \\
\text { on traditional ecological knowledge; joint intercultural educational } \\
\text { programs, ecotourism, and other sustainable development projects. }\end{array}$ \\
\hline $\begin{array}{l}\text { Government Office of the } \\
\text { Chilean Antarctic Province }\end{array}$ & L-R & $\begin{array}{l}\text { Political coordination with other public services and ministries; policy } \\
\text { making for the Cape Horn Region; overseeing public and private investment } \\
\text { in development; and establishing criteria for sustainable tourism. }\end{array}$ \\
\hline Municipality of Cape Horn & L- R & $\begin{array}{l}\text { Supervisor and supporter of Omora activities at the local school; } \\
\text { collaboration in the implementation of Agenda } 21 \text {. }\end{array}$ \\
\hline \multirow[t]{3}{*}{$\begin{array}{l}\text { Chilean National } \\
\text { Environmental Commission } \\
\text { (CONAMA) }\end{array}$} & L-R & $\begin{array}{l}\text { Joint workshops and preparation of television programs and educational } \\
\text { materials for the Regional Environmental Education Program; partnership in } \\
\text { the Environmental Certification Program for Regional schools. }\end{array}$ \\
\hline & $\mathrm{N}$ & $\begin{array}{l}\text { Implementation of the Chile Trail, its southernmost section lies within the } \\
\text { Omora Park; definition of Priority Sites for the Protection of Biodiversity. }\end{array}$ \\
\hline & I & $\begin{array}{l}\text { Collaboration in Chile's program for the implementation of the Convention } \\
\text { of Biological Diversity. }\end{array}$ \\
\hline \multirow[t]{3}{*}{$\begin{array}{l}\text { Chilean National Forestry } \\
\text { Service (CONAF) }\end{array}$} & L-R & $\begin{array}{l}\text { Elaboration and overseeing of forestry management plans, especially for } \\
\text { firewood. }\end{array}$ \\
\hline & $\mathrm{N}$ & $\begin{array}{l}\text { Administration of the System of National Protected Areas, including } \\
\text { national parks and reserves. }\end{array}$ \\
\hline & I & Focal Point of the Man and Biosphere Program (UNESCO) in Chile. \\
\hline \multirow[t]{2}{*}{$\begin{array}{l}\text { Wildlife Department of the } \\
\text { Chilean Agriculture and } \\
\text { Livestock Service (SAG). }\end{array}$} & L-R & $\begin{array}{l}\text { Partnership and scientific advising in the Invasive Exotic Fauna Control } \\
\text { Program for the Magellanic Region; collaboration in the enforcement of } \\
\text { hunting laws, and regulations associated with development of a sustainable } \\
\text { regional cuisine based on native and exotic fauna and flora. }\end{array}$ \\
\hline & $\mathrm{N}$ & $\begin{array}{l}\text { Collaboration regarding bird-banding programs in Chile, and control of } \\
\text { exotic species in general. }\end{array}$ \\
\hline $\begin{array}{l}\text { Chilean Tourism Office } \\
\text { (SERNATUR) }\end{array}$ & $\mathrm{R}-\mathrm{N}$ & $\begin{array}{l}\text { Joint development of innovative topics, narratives and information for } \\
\text { ecotourism (see Table } 3 \text { ). }\end{array}$ \\
\hline
\end{tabular}


L-R Collaboration with regional museums, public libraries, and the Chilean Antarctic Institute (INACH).

Universities and research institutions

Networks

Volunteer Programs
L-R-I

International volunteer programs such as Teaching and Projects Abroad ${ }^{\mathrm{e}}$ or the Earthwatch Institute ${ }^{f}$ have been very valuable in creating a dialogue between local and international students, and helping provide continuity to long-term projects such as the banding program of forest birds at the Omora Park, which has completed 6 yr of continuous data on bird populations of Navarino Island (Anderson and Rozzi 2000, Anderson et al. 2002, Ippi et al., unpublished manuscript). Volunteer opportunities also aide in the formation of students from the University of Magallanes.

\footnotetext{
${ }^{a}$ http://www.uga.edu/ethnobot/Sis.html.

$\mathrm{b}$ http://www.audubon.org.

c http://www.avina.net.

$\mathrm{d}$ http://www.uci.ac.cr/especiales/rirb.asp.

e http://www.teaching-abroad.co.uk/destinations/tpa in/chile.php.

$\mathrm{f}$ http://www.earthwatch.org.
} 
Fig. 4. Scheme showing a cycle of steps from scientific knowledge to conservation actions and back to research again, illustrated by the example of the "Miniature Forests of Cape Horn" program.
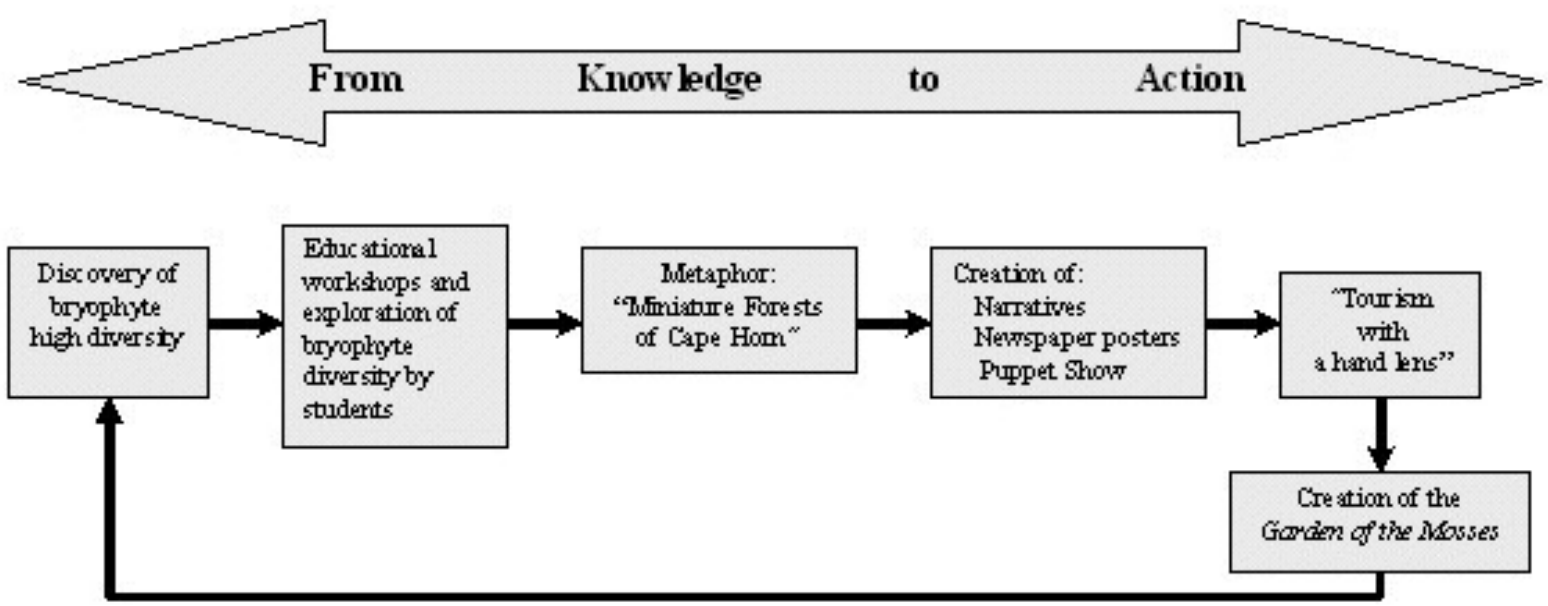

\section{THE OMORA ETHNOBOTANICAL PARK INITIATIVE}

The Ethnobotanical Park Initiative (OEP) was created in 2000 to provide a "physical and conceptual space" for long-term scientific research, interdisciplinary environmental education, and biocultural conservation initiatives. As a physical space, it constitutes a biological reserve that protects the Robalo River watershed, the source of drinking water for the town of Puerto Williams. Across the watershed, one encounters a diverse mosaic of habitats and biotic communities from the shoreline to the highest mountains of Navarino Island (Fig. 2). For this reason, the National Environmental Commission (CONAMA) designated OEP as a priority site for biodiversity conservation (Rozzi et al. 2004).

As a conceptual space, the ethnoecological research and educational programs of the park integrate sciences, philosophy, and arts. In the forest, peat bog, coastal, and alpine habitats researchers develop interdisciplinary methods and share knowledge about austral biocultural diversity with local, national, and international participants. In this way, the park functions as a natural laboratory, an outdoor classroom and training center, and a biocultural reserve, whose functions are incorporated into three broad domains of action: (1) interdisciplinary scientific research; (2) formal and informal education through school, university, and training courses; and (3) biocultural conservation linked with environmental decision making and local sustainable development (Fig. 3).

\section{TEN GUIDING PRINCIPLES FOR BIOCULTURAL CONSERVATION}

With the aim of integrating the three domains of action, research, education, and conservation, and of effectively implementing the goals of ecological, social, and economic sustainability in the Chilean Antarctic Province, we define 10 principles that guide the actions of the Ethnobotanical Park Initiative (OEP) (Table 1, Appendix 2). 
Fig. 5. Communication with the media has allowed Omora to overcome the isolation of Cape Horn and reach a broader audience with novel topics on biocultural conservation. This article reports the visit of the president of Chile, Ricardo Lagos, to the Omora Park (La Prensa Austral, 28 February 2001).

\section{Proyecto Omora en Williams \\ Lagos conoció parque en el sur del mundo}

Parte importante de la reciente visita del Presidente Ricardo Lagos aPuerto Williams, la constituyó un recorrido al Parque Etnobotánico Omora, el más austral del mundo.

Eduardo Barros, gobernador de la provincia Antártica, destacó que luego de conocer los aspectos generales del proyecto, Lagos decidió incluir en su programa un recorrido al parque Omora, distante 2 kilometros de la austral ciudad. El proyecto asocia a la Ong Omora, la Universidad de Magallanes, la comunidad Yagán, el Museo Martín Gusinde y la Gobernación de la provincia Antártica.

El ecólogo Ricardo Rozzi, presidente de la Fundación Omora, explicó a Su Excelencia que el programa del parque integra la investigación científica, la educación y el desarrollo sustentable. Sus objetivos son articular el bienestar social y la conservación biocultural, promover la educación intercultural e investigar los vínculos ecológicos y biogeográficos entre las regiones antárticas y subantárticas de Chile.

"Lo importante es entender que los sistemas ecologicos sustentan los sistemas productivos y económicos", indicó. Por ejemplo, reflejar la relación entre los bosques templados más australes del planeta y los sistemas marinos subantárticos, o nutrientes que proveen los cursos de agua dulce para los recursos naturales marinos, como la centolla.

El recorrido

Asimismo, el proyecto

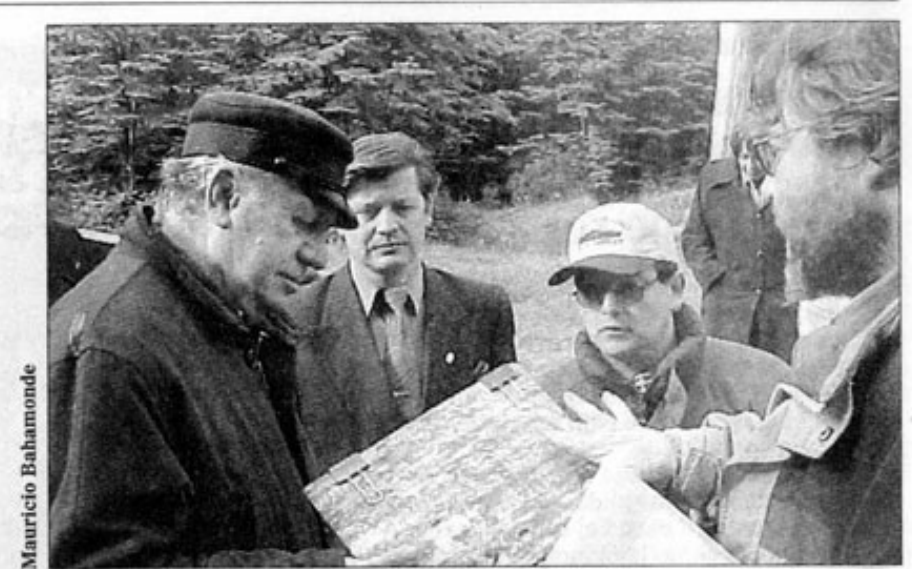

Ricardo Rozzi le entrega al Presidente Lagos el programa del parque Omora para el desarrollo local sustentable y el ecoturismo en la provincia Antártica, junto al gobernador Eduardo Barros y el alcalde de Navarino, José Soto Passek. Al fondo, la intendenta Nelda Panicucci. investiga y valoriza el cono- a través de bosques turismo de especialidades. cimiento tradicional que la siempreverdes (coigüe "Los visitantes que llegan etnia yagán posee sobre los de Magallanes), bosques hasta el cabo de Hornos vieecosistemas subantárticos, subantártico de ñires y nen atraídos por intereses Lagos conoció la participa. parque de lenga. También especiales como la naturación de los dirigentes de conoció el programa de leza y antropología, el disesta comunidad en la cons- anillamiento de aves mi- curso de nuestro parque es trucción y diseño del par- gratorias, destacándose el entregar información conque botánico, y observó las estudio del Fío-fío, ave que fiable y relevante a guías denominaciones en lengua vuela todos los años desde de turismo locales", indicó yagán de las plantas y aves el Amazona hasta el cabo Rozzi. También preparan que forman el sendero inter- de Hornos, donde se repro- materiales complementapretativo del parque. duce en cada primavera y

En menos de una hora, pudo apreciar el variado mosaico de ecosistemas subantárticos, caminando verano.

El proyecto busca transformarse en un aporte al desarrollo local a través del rios como una guía de aves, una guía de líquenes y la eventual implementación de una estación biológica y un centro de visitantes.

\section{(1) Interinstitutional Cooperation}

The OEP is an interinstitutional initiative at two levels: that of land-tenure and park function. In terms of land tenure, the Chilean Ministry of National Land granted the park jointly to a private nonprofit organization, Omora NGO, and a state institution, i.e., the University of Magallanes, as a renewable 50-yr free concession of $800 \mathrm{ha}$. Sited on state land, the OEP has generated an innovative model of public-private collaboration for conservation.
The perception of the park as a shared public-private initiative has stimulated interinstitutional work among a broad array of agencies. In turn, interinstitutional collaboration permitted Omora scientists to play a critical leadership role in environmental decision making (Table 2). Omora's long-term research and education programs have also benefited from collaborative projects and agreements with Chilean and foreign universities and research institutions. 
Fig. 6. Omora initiative emphasizes field experiences and direct or immediate encounter with other living beings. Through this educational approach, Omora Park counterbalances the excess of "mediated information," which prevails in formal and informal education. Presently, most of our knowledge about nature is mediated through established scientific narratives, e.g., Darwin's Voyage of the Beagle, through technological media such as TV or computers, e.g., videotape of the firecrown hummingbird visiting Philesia magellanica flowers, and/or by mathematical models and equations, e.g., the hummingbird Omora is studied through an equation for metabolic rate of Sephanoides sephaniodes. Equation taken from López-Callejas and Bozinovic (1995).

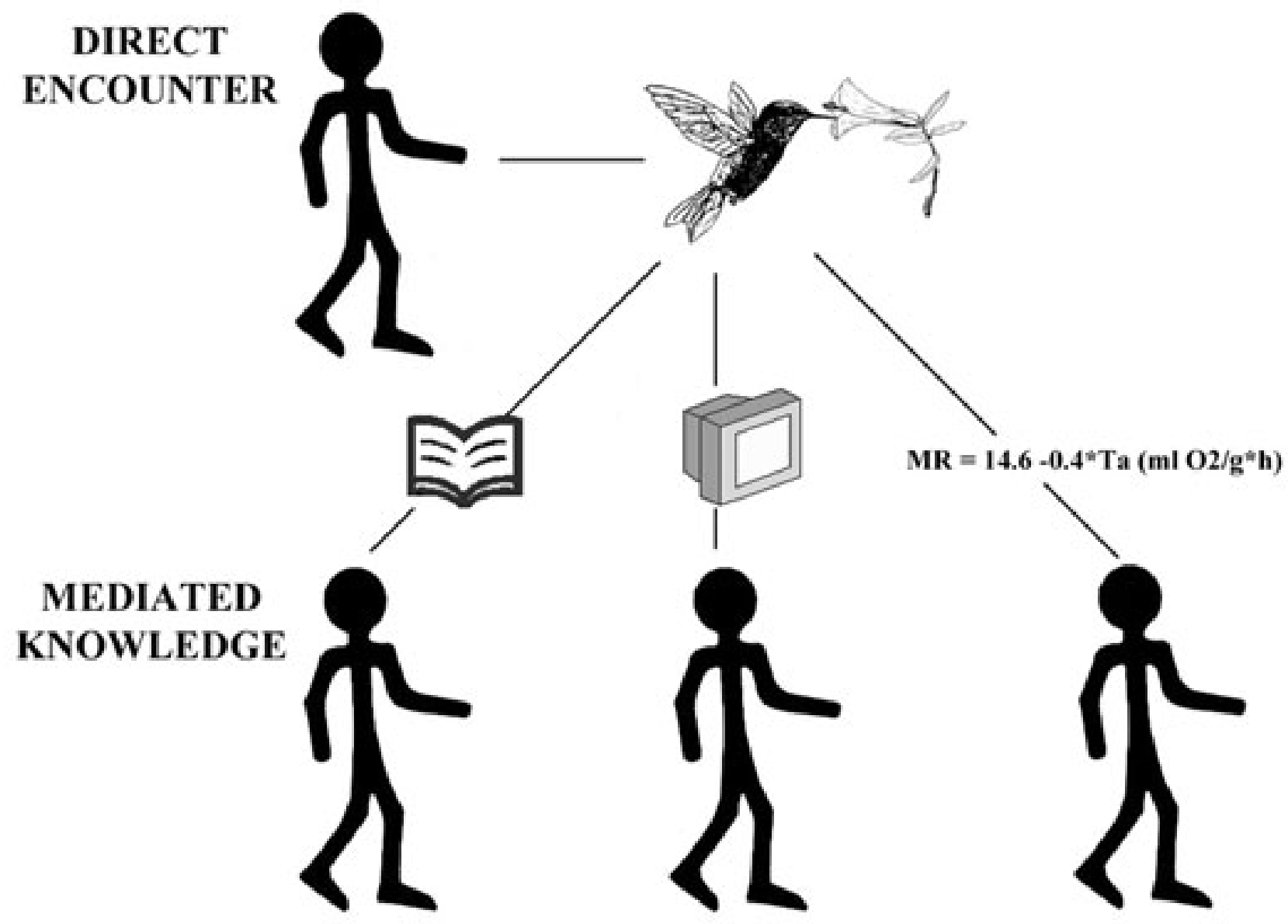

\section{(2) Participatory approach}

A central cultural objective of the creation of Omora has been to work together with the indigenous Yahgan community, which is the reason that the adjective ethnobotanical is included in the park's name. In fact, several of the current elders of the Yahgan community were born in the park when it was Robalo Ranch from 1910 to 1970 . Today, the Yahgan community lives in Ukika village $5 \mathrm{~km}$ to the east of the park, but all of the Yahgan people have open access to the park's land. For example, Yahgan women can gather rushes for basketry. Collaboration with the Yahgan community also involves participation in research and educational programs, maintenance of trails, and guiding visitors. Their contribution to the park is essential as their unique traditional ecological knowledge complements and nourishes the scientific, educational, and conservation programs. 
Table 3. Diversification of tourism thematic areas in Cape Horn. Omora scientists are developing these new topics through the preparation of guidebooks and training courses for tourist guides with the support of the regional government.

\begin{tabular}{ll}
\hline \hline New Tourism Themes & Tourism Activities \\
\hline Tourism with a hand lens & $\begin{array}{l}\text { Guided tours to explore the beauty of the diverse lichens, mosses, and } \\
\text { liverworts of the world's southernmost forest and tundra ecosystems (Goffinet } \\
\text { et al. 2006) }\end{array}$ \\
$\begin{array}{ll}\text { The path of Darwin in Cape Horn and its } \\
\text { influence on the development of his } \\
\text { theory on human evolution }\end{array}$ & $\begin{array}{l}\text { Guided tours to places visited by Darwin around the Cape Horn Archipelago, } \\
\text { focusing on those that inspired the young naturalist to conceive his theory of } \\
\text { human evolution (Rozzi and Heidinger 2006) }\end{array}$ \\
$\begin{array}{l}\text { The mosaic of land-seascapes of Cape } \\
\text { Horn }\end{array}$ & $\begin{array}{l}\text { Guided tours that invite tourists to look at the southern tip of the Americas with } \\
\text { an ecosystem perspective, which enhance the appreciation of the unique and } \\
\text { diverse mosaic of pristine landscapes in Cape Horn (Rozzi et al. 2006 }\end{array}$ \\
$\begin{array}{l}\text { Indigenous Yahgan ecological } \\
\text { knowledge }\end{array}$ & $\begin{array}{l}\text { Guided tours that interrelate the biological diversity of Cape Horn with the } \\
\text { Yahgan culture, linking this appreciation to the current Yahgan handcraft } \\
\text { industry that still uses tree bark, rushes, and whalebones (Massardo and Rozzi } \\
\text { 2006). }\end{array}$
\end{tabular}

To develop a rapport and a basis of trust with the members of the Yahgan Community, no photographs of Yahgan people were taken by the scientists involved in Omora during the first year of the park's operation. Given their tragic history of encounters with colonists, they were familiar with, and dreaded, being merely considered as "objects of study." In addition, no money was exchanged. We engaged exclusively in nonmonetary interactions to initiate common activities. Particularly important was helping Yahgan children in their performance at the local school, where they were often discriminated against (Rozzi et al. 2003a). The Omora program helped the regional education officials to understand that the learning problems of Yahgan students had to do with the dissociation of the educational program from the local biological, cultural, and social realities in the Cape Horn region, rather than learning capabilities (Rozzi 2002). As a result, the Yahgan community valued the Omora initiative and helped to design and build the entrance and trails of the park, and several research expeditions were conducted on boats operated by Yahgan fishermen.

An indication of the success of this approach was the progress to a second phase in the development of a sustained relationship with the Yahgan community in which joint projects were prepared. We have worked collaboratively, for example, on developing Yahgan language educational materials and workshops, which involved the participation of Yahgan elders and children together with ecologists, anthropologists, and artists. These projects were especially important because they help rescue a dying language through organized programs for children, and with published educational materials such as a Yahgan dictionary, illustrated by the children (Zárraga et al. 2006), and a bird guide incorporating Yahgan traditional ecological knowledge (Rozzi et al. 2003b).

The long-term residence of researchers and graduate students at the OEP has been essential to developing mutual understanding and collaborative projects with the indigenous community. Each scientist associated with Omora is requested to include educational and/or conservation activities with their research projects, and not simply go into the field to collect data and then quickly return to their home institutions to analyze and publish the results of their studies. To implement our participatory approach, it has been critical to share work and everyday life. This approach avoids some of the incomplete 
Fig. 7. The Cape Horn Biosphere Reserve includes the archipelago south of Tierra del Fuego Island. On the southwestern peninsula of Tierra del Fuego, the biosphere reserve also includes the Darwin Mountain Range. It is the only Chilean biosphere reserve that comprises terrestrial and marine ecosystems, and is the largest of southern South America, i.e., Uruguay, Argentina, Chile, by extending over an area of $48,843 \mathrm{~km}^{2}$ composed of $19,172 \mathrm{~km}^{2}$ and $29,670 \mathrm{~km}^{2}$ of terrestrial and marine areas, respectively.

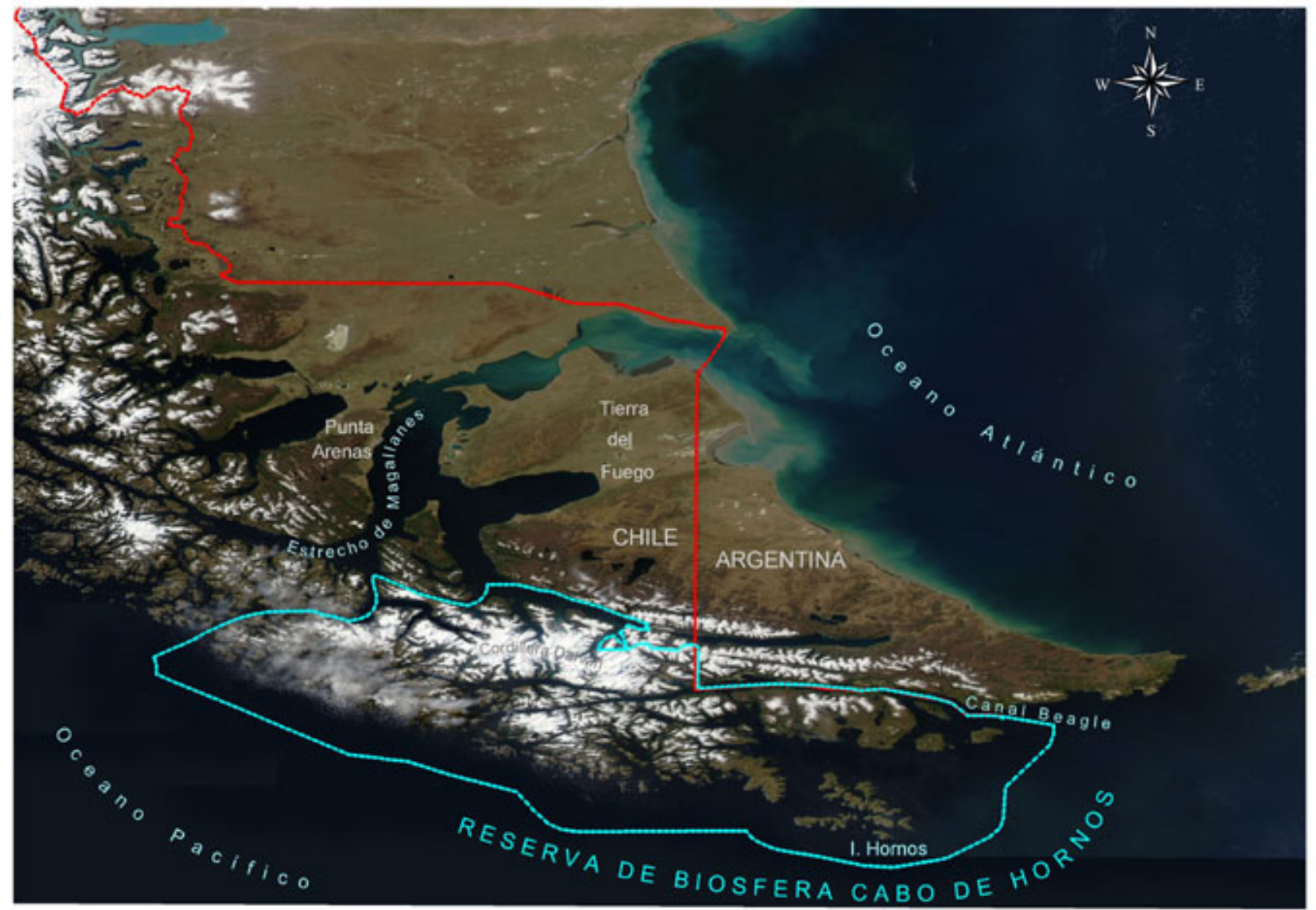

perspectives and biases that derive from the prevailing participatory approaches based on shortterm interviews or workshops, typically offered to indigenous and rural communities by Chilean or foreign consultants (Rozzi 2005).

\section{(3) Interdisciplinary conservation approach}

One of the most stimulating academic and intellectual challenges that Omora faces is the bridging of the humanities and sciences. This interdisciplinary integration has been achieved by turning scientific concepts into conservation actions, as illustrated by the work with the austral cryptogamic flora (Fig. 4). In 1999, North American 
Fig. 8. The number of Yahgan bird names that are known to science continues increasing until today. For example, for forest bird species of the Cape Horn region, Charles Darwin (1839) did not register Yahgan names. Later, in the 1870s, the Anglican missionary Thomas Bridges included in the manuscript of his Yahgan-English dictionary, Yahgan names for 16 species, among them lana for the Magellanic woodpecker (Campephilus magellanicus). In the 1920s, the ethnographer Martin Gusinde continued discovering new Yahgan bird names, for example, Omora for the firecrown hummingbird (Sephanoides sephaniodes). More recently, in the 1980s the linguists Maria Teresa Poblete and Adalberto Salas (1997) added names for three other bird species, including the Andean condor (Vultur gryphus) or wariao in Yahgan. Finally, our own work has raised the number of known Yahgan names for forest bird species to 38 , including names for nocturnal birds such as kujurj for the rufous-legged owl (Strix rufipes) (Rozzi 2002, Massardo and Rozzi 2004). Figure modified from Rozzi et al $2003 \mathrm{~b}$.

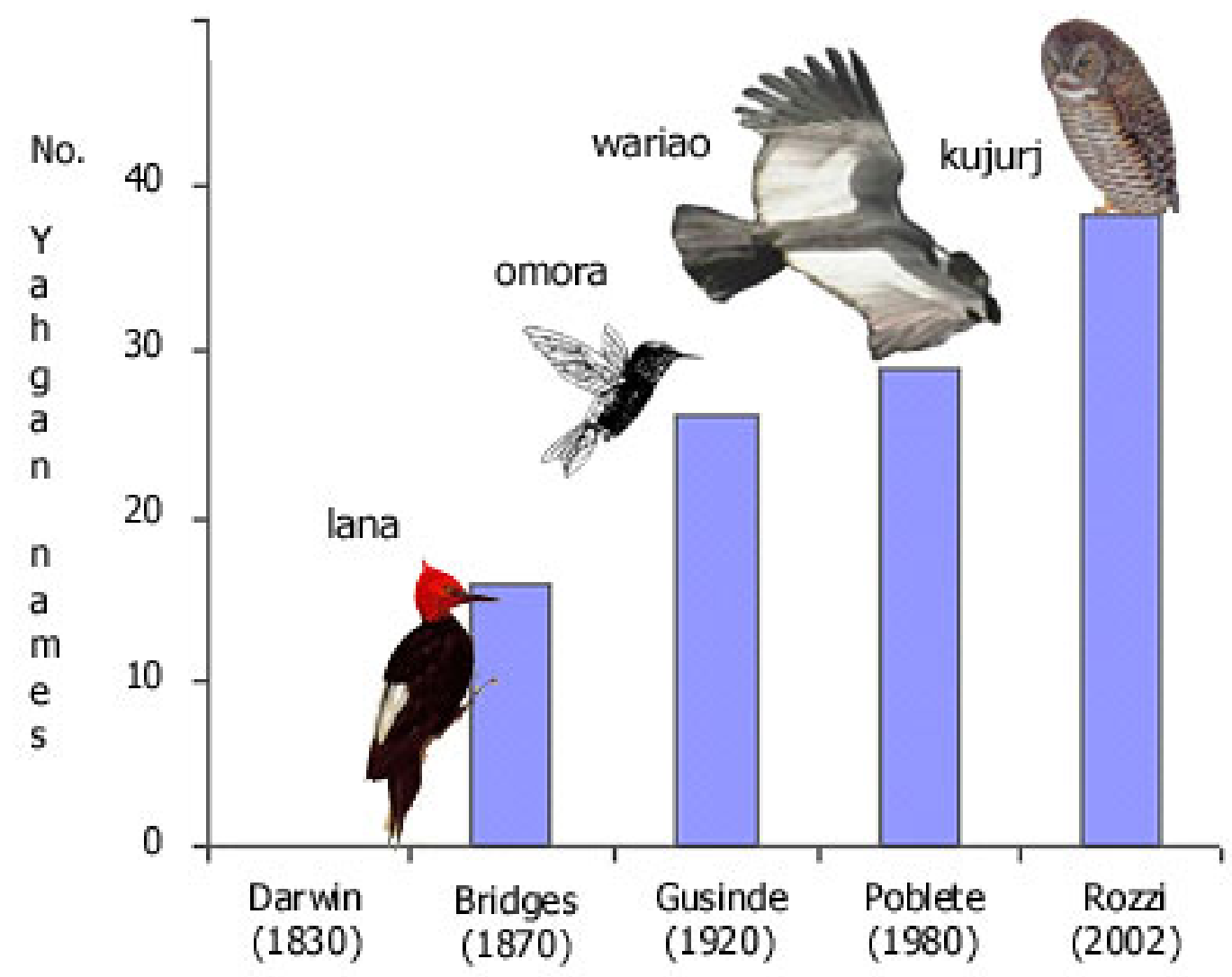

and British bryologists working with the OEP initiated floristic studies, which led rapidly to the discovery of new species of mosses, liverworts, and lichens in the CHA region (Shaw and Goffinet 2000, Buck and Allen, unpublished manuscript). Researchers found that the subantarctic Magellanic evergreen rainforest ecoregion included at least 818 bryophyte species, i.e., more than $5 \%$ of the 15,000 known worldwide, and has been recently proposed as a world "biodiversity hotspot" for nonvascular plants (Rozzi 2005, Rozzi et al., unpublished manuscript).

Omora's discovery of new moss species, in turn, 
alerted the public and politicians alike to how much remains to be learned about what soon became known as "austral microbiodiversity." This metaphor denoting small organisms triggered an educational program, supported by the Chilean National Science Foundation, which gave rise to the organization of graduate-level field courses on bryophytes in the park. The graduate students reinforced the elementary school educational program, focusing on "the miniature forests of Cape Horn." This new metaphor promoted general appreciation about the beauty of these small plants and of the biotic communities with which they are associated. A series of posters circulated as inserts in the regional newspaper, and a musical puppet show helped to communicate to the public the rich diversity and life histories that take place in the miniature forests of mosses and lichens (Ippi and González 2004).

The journey came full circle as this information and education was transferred to ecotourism via an additional metaphor and activity: "tourism with a hand lens." The government enthusiastically endorsed this innovative concept and funded the publication of a field guide. Today, the bryophyte and lichen communities are becoming a unique attraction for austral tourism; even engaging cruise ship passengers (Rozzi 2005). Whether it is entitled "Cape Horn Bryophytes" for a science-funding agency, "Miniature Forests" for education, or "Tourism with a Hand Lens" for business, this project has provided a unique perspective on a flora that has largely been ignored.

As an integrated research, education, conservation, and tourism initiative, this example illustrates a fruitful transition from knowledge to action. A team of botanists, ecologists, teachers, musicians, artists, ecotourism operators, and government authorities were able to incorporate basic scientific methods and new knowledge into education, and then into conservation and tourism. In turn, these actions stimulated new research questions, thereby establishing a cycle of interdisciplinary collaboration that reinforces science's social relevance (Fig. 4).

\section{(4) Networking and international cooperation}

The miniature forests of Cape Horn example demonstrate the critical role that collaboration between local and international partners can play in the generation of innovative scientific research and effective regional conservation. This program would not have been possible without international collaboration, due to the lack of trained Chilean bryologists and taxonomists (cf., Simonetti et al. 1995).

International collaboration is also needed because today's environmental problems are no longer purely local or regional. International partnerships facilitate both the implementation of solutions to these problems and the identification and characterization of their causes (Rozzi and Feinsinger 2001). To address such multiple-scale environmental problems, Omora established linkages with other regions of Latin America and the world and has organized its cooperative approach hierarchically (Table 2). For example, Omora collaborates with the Chilean National Environmental Commission (CONAMA). This involves: (1) locally, developing environmental education workshops and materials for children, teachers, authorities, and the local community; (2) regionally, working on environmental certification programs for schools, and the creation of the Cape Horn Biosphere Reserve; (3) nationally, providing information for defining priority sites for biodiversity conservation; and (4) internationally, helping Chile fulfill its responsibilities for the implementation of the Convention on Biological Diversity (Table 2).

\section{(5) Communication through the media}

"What is not communicated does not exist" was the maxim that the governor of the Chilean Antarctic Province coined at the beginning of Omora's project. By communicating its discoveries, activities, and projects through newspapers, television, and radio, Omora has overcome the isolation of the remote austral archipelago. As a result, Cape Horn biocultural conservation has become a central topic in the public dialogue of the Magellanic region and Chile.

The narratives that Omora has generated through documentary films, nature television series, radio programs, articles in newspapers, and even fashion magazines has helped to create public validation of this conservation initiative (Fig. 5). Collaboration with journalists has contributed to a diversification of the perspectives that the public has about the austral biodiversity and its relationship with social well-being in Magallanes. 


\section{(6) Flagship species}

Another pivotal element of our conservation initiative was the identification of a flagship species: the green-backed firecrown hummingbird (Sephanoides sephanoides), or Omora, in the Yahgan language. The focus on the firecrown was appealing to the diverse stakeholders who live in Puerto Williams. Directing the attention toward a biological species helped the Omora initiative reverse some sociocultural prejudices that Yahgan indigenous people were facing (Rozzi et al. 2003a). Although Omora is a Yahgan name, the use of the symbol of the hummingbird by the ethnobotanical park avoided a bias toward a particular social group: in fact, it invited the Yahgans to be included in a substantial and respectful way in the park's educational and research programs. In addition, as a flagship species, the firecrown embodies the integration of biological, ecological, anthropological, social, and cultural dimensions that motivate the Omora initiative.

From a biological point of view, hummingbirds constitute an exclusively American family of birds (Trochilidae), and more than $95 \%$ of its 330 species are restricted to tropical latitudes (Greenewalt 1990, McGehee et al. 2002). Sephanoides sephanoides is the only hummingbird species that reaches the extreme southern tip of the continent, and its presence at such a high latitude attracts the attention of scientists, especially regarding the bird's responses to the rigorous climatic conditions in the area, the quality of flower nectar, and the energetic requirements of the birds (Massardo et al., unpublished manuscript).

From a cultural point of view, Omora is a central figure in the Yahgan cosmology (Gusinde 1961). In the Yahgan narratives Omora is seen as a bird, yet at the same time it is seen as a small person, a spirit who maintains social as well as ecological order (Appendix 3). Additionally, Yahgan stories about Omora concur with contemporary scientific understanding about the need for conservation of bird communities in the region of Cape Horn. Birds contribute to ecological processes such as pollination, seed dispersal (Anderson et al. 2002), and nutrient cycles including transport of minerals between marine and terrestrial ecosystems (Pisano 1981). These ecological processes are essential to the conservation of the flora in watersheds; and therefore, the regulation of hydrologic flows. Consequently, the establishment of the OEP as a reserve to protect the biodiversity of the Robalo River watershed is a measure recommended by both the scientific ecosystem analysis and the Yahgan narrative of Omora.

From the perspective of environmental ethics, both scientific and Yahgan views support an "instrumental value" of biodiversity because its conservation is an "instrument" for the continuity of water supply (Rozzi 2004). In addition, the initial statement of Omora's narrative "in ancestral times when birds were human beings," parallels the scientific theory about a common evolutionary origin and biological nature shared by humans and birds (Rozzi et al. 2003a,b). These notions of kinship between birds and humans support a sense of intrinsic value of biodiversity because birds are perceived as our distant evolutionary relatives. Hence, the existence of birds could be subject to moral considerations equivalent, to some degree, to those with which we judge the value of human life (Rozzi 2004).

In summary, Omora is a flagship species that provides the name for the park and "embodies," in a comprehensive and appealing image, goals that have both scientific and social perspectives. The utility of an effective flagship species has been demonstrated in other conservation initiatives (cf., Walpole and Leader-Williams 2002, Krüger 2005).

\section{(7) Outdoor education}

The educational program of the OEP emphasizes "direct encounter" with mosses, lichens, trees, rocks, waters, birds, other living beings, both humans and nonhumans. These outdoor educational experiences are designed to stimulate perceptions of biological and cultural diversity at a given site. Through its emphasis on physical contact with nature, the educational experience at Omora counterbalances the excess of "mediated information" that prevails today in formal and informal education. Most of our knowledge about nature is "mediated" by mathematical models and equations, logical frameworks, and/or established scientific narratives, and technological media such as TV or computers (Fig. 6). Direct exposure to natural habitats is becoming an increasingly rare experience (Leopold 2004, Smith 2004). For this reason, the Omora educational approach encourages crossing the barriers of mediation by promoting intimate encounters with marine and terrestrial beings. 
Modern science believes that it is possible to express the essence of the natural world and its natural laws by means of mathematical formulas (Bowler 1993). Our approach of direct acquaintance with nature and its diversity has enabled students to better ponder the widespread modern scientific view of nature expressed in mathematical representations, and more recently by computer models. The OEP started a series of "field environmental philosophy" workshops to experientially deconstruct such universal and mathematical assumptions about nature, through the rediscovery of the singularities of each living being, and of the inapprehensible diversity of beings. This type of field experience has enabled students, teachers, scientists, citizens, and policy makers to recover awareness about the integral lives of singular living beings beyond their mathematical representation or scientific names.

Researchers facilitate this type of inquiry into biocultural diversity by involving visitors in description and depiction activities, and by posing questions that are answerable "at first hand," without using sophisticated or costly instruments, and within a timeframe that is convenient for the students (Feinsinger et al. 1997, Rozzi et al. 1997). This process-oriented approach contrasts with the content-oriented approach emphasized in formal and informal education today.

The understanding gained through this educational process leads not only to a conceptual awareness of biological and cultural diversity, but also to an emotional feeling and sense of involvement. This has proven to be an experience critical for motivating politicians and decisions makers (Barros and Harcha 2004).

\section{(8) Economic sustainability and ecotourism}

The educational approach outlined above inspired tourism at the OEP. Tourists meet researchers, e.g., senior scientists, graduate students, and local research assistants, and engage in a peripatetic dialogue, an interactive process of observation, dialogue, and inquiry while exploring the trails. Researchers act as "Socratic facilitators," who allow tourists to observe and discover biocultural diversity by themselves, achieving a more holistic and lasting learning experience than that provided by a mere unilateral transmission of biological, cultural, or historical facts (cf., Feinsinger et al. 1997).

The OEP has contributed to the development of ecotourism in Cape Horn via direct and indirect ways. Directly, the OEP itself has become a tourist attraction (Hubbard et al. 2003). Indirectly, the OEP contributes by: (1) defining criteria for sustainable tourism practices, and (2) diversifying tourism narratives through the incorporation of new content and practices that let visitors appreciate and enjoy biocultural diversity (Table 3).

The OEP, however, is not financed by tourism. Economic sustainability of the park primarily comes from its network of collaborators and projects. For instance, support from the Millennium Institute of Ecology and Biodiversity helps the OEP form part of a nascent network of long-term ecological research sites that covers the whole latitudinal range of Chilean temperate forests $\left(30-56^{\circ} \mathrm{S}\right)$. As a result, the park's economic sustainability comes from implementing Principles 1 and 4.

\section{(9) Administrative sustainability}

For the administrative sustainability of the conservation initiative, we defined two levels: the OEP and the regional scale of Cape Horn Archipelago. At the park level, the alliance with the University of Magallanes (UMAG) has allowed the establishment of long-term research and education programs through continuous work by graduate students. In turn, Omora was instrumental in creating the UMAG Master's program in "Conservation and Management of Subantarctic Natural Resources," which was the first of its kind in the austral region. Additionally, the OEP is consolidating its international dimension with the creation of an interdisciplinary field station to integrate environmental philosophy, sciences, and policy in collaboration with the Department of Philosophy, University of North Texas. Therefore, as with economic sustainability, administrative sustainability of the OEP relies on implementing Principles 1 and 4.

In order to build an administrative platform that contributes to sustainability at the regional level, the OEP has led a 5-yr process involving the participation of a broad array of local and regional actors to help in creating the Cape Horn Biosphere Reserve (CHBR) (Fig. 7, Table 2). The designation of the CHBR by UNESCO's Man and the Biosphere Program (MaB), in June 2005, promoted the integration of conservation criteria into regional planning and decision making on a formal institutional basis. Interestingly, there are 
noteworthy parallels between the approach and the goals of the OEP and the MaB's Biosphere Reserve program. According to the MaB's Seville Strategy (1996), "biosphere reserves should complete three complementary functions": (1) biodiversity conservation; (2) sustainable economic and human development; and (3) logistic support for research, education, training, and monitoring.

Today, the Chilean government recognizes the CHBR as a model for implementing some of its own obligations derived from international environmental agreements. The CHBR provides an actual example of implementing the goals of the Convention of Biological Diversity, signed and ratified by Chile in 1994: (1) conserving biodiversity, (2) equitable sharing of benefits, and (3) sustainable use of biodiversity. In summary, through the creation of the CHBR, the Omora initiative generated a longterm, institutionalized administrative platform to project the goals of conservation and social wellbeing to regional, national, and international levels.

\section{(10) Research and conceptual sustainability for conservation}

Finally, we have defined "conceptual sustainability," understood as a continuously evolving process for perceiving, understanding, and co-existing with biocultural diversity, as a key component of the OEP's long-term viability. First, exploration and research activities are necessary practices for discovering that which we want to conserve. Second, ecological and social systems constantly change; therefore, research needs to be continuous and adaptive. Finally, the fascination derived from the discovery of novel attributes and processes of the wild ecosystems of Cape Horn and the pleasure of reaching new understandings about the cultural relations established by diverse human groups with the southern environments keep students and researchers interested in doing long-term research under the rigorous environmental conditions at the end of the world.

The OEP's continuous process of raising questions has shown how peoples' knowledge and values vary over time (Rozzi et al., unpublished manuscript). These results have, on the one hand, cautioned decision makers about the limitations of the prevailing "consultant approach" that produces one time "snapshots" of information. On the other hand, they have alerted authorities to how challenging, but necessary, it is to continuously study, perceive, understand, and live together with the austral biological and cultural diversity (Rozzi et al. 2003a). An historical analysis of the Yahgan names for forest birds helps to illustrate this point.

In the Voyage of the Beagle, Charles Darwin described the Yahgan language as a "chuckling kind of noise, as people do when feeding chickens" (Darwin 1839). Forty years later, Darwin was able to revise this assessment after he received a manuscript for a Yahgan-English dictionary from the Anglican missionary Thomas Bridges that included more than 32,000 words (Bridges 1933). This work made such a strong impression on Darwin that he radically transformed his point of view, and the intellectual attributes of the Fuegian-Yahgans influenced his evolutionary arguments in favor of the similarities among human ethnicities and races (Rozzi 1999, Rozzi et al. 2003a).

Since Bridges' publication, researchers have continue discovering significantly more Yahgan terms for naming and understanding the biodiversity of Cape Horn. Figure 8 highlights the difficulties of perceiving biocultural diversity by illustrating the slow process of discovering the Yahgan names for forest birds. If scientists have had such difficulties perceiving and understanding this language, then how much more "invisible" will its richness be to policy makers and society? Our current environmental crisis is, to a major extent, a "cognitive crisis," because as a society we constantly fail to perceive the richness of the biocultural diversity with which we coexist. OEP emphasizes the importance of continuous research to address this challenge in unique regions such as Cape Horn.

\section{CONCLUSIONS}

More than conservation science, this article is about a "conservation practice," which characterizes a strategy that allowed the incorporation of essential ecological and cultural attributes and values of the Cape Horn region into social and political decision making. To better distinguish our approach, we can contrast it with the Rio Condor project, which adopted a research approach and concentrated on scientific questions, researched over four months on Tierra del Fuego Island, just north of Cape Horn County (Arroyo et al. 1996). Rio Condor produced extensive scientific reports, which were delivered 
to the regional government and published in peerreviewed journals, but did not involve the government in the design and decision-making process. Unexpectedly, this large-scale project, involving the Chilean National Academy of Science and nearly 100 researchers, failed in its attempt to establish sustainable forestry and biological reserves in Tierra del Fuego (Klepeis and Laris 2006).

In contrast, the Ethnobotanical Park Initiative (OEP) began as a small-scale research project, which in partnership with regional authorities and other actors developed into a conservation initiative. The key innovation made by the OEP ecologists was to become involved as "conservation facilitators," collaborating with other partners, rather than adopting a "pure researcher" approach. Omora's set of guiding principles, outlined above, describes how conservation actions were organized to establish partnerships and communication with various actors and stakeholders.

The first four principles, interinstitutional, participatory, interdisciplinary, and local-international networking, encompass four basic strategies that are necessary to identify and incorporate relevant processes and participants into the initiative. Continuous participation of a team of national and international scientists with indigenous people as much as with authorities facilitated a process of dialogue. The Cape Horn Biosphere Reserve (CHBR) proposal then involved multiple, crossscale interplays of institutions with both horizontal and vertical linkages (Rozzi et al. 2006b), and both bottom-up and top-down directions of decision making were included in the process.

The next three principles have been essential for uniting and involving the diverse array of stakeholders in the Omora initiative: (1) media communication has generated a common understandable and persuasive narrative; (2) the hummingbird flagship species helped go beyond human-centered decision making; and (3) the recurrent educational experiences in the field have generated a sense of friendship, as well as a sensitive understanding and emotional engagement among the diverse actors and with the other components of the ecosystems of Cape Horn.

By emphasizing the need for research, the last three principles set out a three-dimensional approach to achieving sustainability, which goes beyond the traditional focus on socioeconomic and environmental dimensions. The continuous participation of researchers in the generation of a common understanding about eco-social systems, environmental decision making, and the creation of alternatives for sustainability has been more effective than just creating scientific knowledge and assessments. The Omora approach entails a social involvement from scientists, which goes beyond "transferring scientific knowledge to society" or "informing policy and management decisions" (cf., Lubchenco 1998). Omora researchers not only produced scientific knowledge to be considered by other agents, but they also entered an interinstitutional process of discussion about ecological and social perspectives, which enabled the emergence of new concepts and practices.

We cannot conclude this article, however, without mentioning the major challenges to implementing and sustaining conservation actions in the Cape Horn region. Geographical and technological isolation, compounded by severe climatic conditions and lack of basic services, increased the logistical difficulties in the region. In a "frontier town," like Puerto Williams, without the resources taken for granted in more populated areas, scientists were required to learn multiple practical skills. In a bottom-up project like Omora, scientists have undertaken an extra amount of work by learning to be like "pioneers" to avoid a socially isolated, bubble-like project and to achieve, instead, enduring interactions and mutual understanding with the local community.

The participatory approach has also been extremely demanding because, although participation has created agreements, it has also generated strong disagreements between dissimilar institutions, persons, languages, and interests within and outside the region. The participatory process has made it apparent how the experiences and perspectives of decision makers and conservationists in large cities or international organizations often differ from those held by members of the local community. Differences in perception and everyday life experience constitute fundamental barriers to genuine communication, agreements, and coordination between local- and global-scale stakeholders (Rozzi et al., unpublished manuscript). To overcome these barriers, Omora's emphasis on working together with the variety of actors, rather than on providing only scientific information, was critical. From the point of view of the regional government, this 
emphasis permitted the establishment of personal and institutional relationships and agreements, which in turn translated into conservation actions, and not only into conservation research or recommendations (Barros and Harcha 2004).

The interinstitutional, participatory, and interdisciplinary approaches of Omora scientists has obliged them to face difficulties derived from prevailing conceptual and professional barriers, and from established policies that reward specialization, compartmentalization, and short-term research projects. Omora's solution to this dissociation has been to satisfy both the traditional needs from academia, i.e., publications and research, and the nontraditional tasks demanded by the biocultural initiative and its variety of actors. Consequently, Omora's approach supports current calls for broadening academic evaluation criteria (Bazzaz et al. 1998).

The creation of the OEP and the CHBR have required profound dedication and resolve of scientists to counter the general lack of academic recognition and social understanding on the part of most professional peers. Current academic evaluation is mainly based on indices of citation in specialized journals (Bazzaz et al. 1998), and for scientists and other professionals, participatory activities demand a great deal of time and dedication, the costs and efforts of which are additional to the research. In spite of numerous calls by ecologists urging scientists to devote part of their professional lives to "stemming the tide of environmental degradation and the associated losses of biodiversity and its ecological services, and to teaching the public about the importance of those losses" (Lubchenco et al. 1991), still little professional value is given to community involvement and conservation activities.

The OEP shows that it is possible to integrate ecological and social dimensions, and to implement international conventions such as the Convention of Biological Diversity, even at the end of the world. In addition to its value for creating a park and a biosphere reserve, OEP's initiative calls attention and open questions about the multiple relationships between ecologists and society implicit in conservation work. At the same time, it proposes 10 interrelated principles to characterize a multidimensional way of doing ecology and conservation that could be evaluated, and eventually adapted, elsewhere across a broad spectrum of conservation initiatives that remain grounded on local levels and at the same time reach up to regional and international levels.

Responses to this article can be read online at:

http://www.ecologyandsociety.org/voll1/iss 1/art43/responses/

\section{Acknowledgments:}

This article relies on the work of countless people. We especially thank the Governor of the Chilean Antarctic Province, Mr. Eduardo Barros, regional and national public service officers, the local community of Puerto Williams, and Marisol Astorga, Orlando Dollenz, and Andres Mansilla at the Universidad de Magallanes. We also thank the numerous resident and visiting Omora students, volunteers, and researchers, particularly Uta and Augustin Berghoefer, Ezio Firmani, and Steven McGehee. John Schwenk at WHUS Radio prepared the audio file for Appendix 3. Baird Callicott, Ron Carroll, Robert Frodeman, Eugene Hargrove, Carl Leopold, Miguel Mansilla, DVora Starr, and two anonymous reviewers provided valuable comments on the manuscript. We appreciate the support of the Millennium Institute of Ecology and Biodiversity (CMEB, PO2-051-F), BBVA Foundation Prize for Research on Conservation Biology, BIOKONCHIL project (FKZ 01 LM 0208, German Ministry of Education and Research, BMBF), Darwin Initiative (grant 13024), and "Programa de Investigación No 247" Universidad de Magallanes. This publication is a contribution to the long-term research program of the Omora Ethnobotanical Park, and the Cape Horn Biosphere Reserve.

Author affiliations:

Ricardo Rozzi $i^{1,2,3,4}$, Francisca Massardo ${ }^{2,3,4}$, Christopher B. Anderson ${ }^{3,4,5}$, Kurt Heidinger ${ }^{1,3}$ and John Silander, $\mathrm{Jr}^{3,6}$.

${ }^{1}$ Department of Philosophy and Religion Studies, University of North Texas, Denton, Texas, USA.

2 Universidad de Magallanes, Puerto Williams, Chile.

3 Omora Ethnobotanical Park, Puerto Williams, Chile.

${ }^{4}$ Institute of Ecology and Biodiversity, Santiago, Chile.

5 Institute of Ecology, University of Georgia, Athens, Georgia, USA.

6 Ecology and Evolutionary Biology Program, University of Connecticut, Storrs, Connecticut, USA. 


\section{LITERATURE CITED}

Alvarez R., F. Massardo, R. Rozzi, U. Berghoefer, A. Berghoefer, and J. Fredes. 2004. Cultural heritage of the proposed Cape Horn Biosphere Reserve. Pages 153-175 in R. Rozzi, F. Massardo, and C. Anderson, editors. The Cape Horn Biosphere Reserve: a proposal for conservation and tourism to achieve sustainable development at the southern end of the Americas. Ediciones Universidad de Magallanes, Punta Arenas, Chile.

Anderson, C., R. Rozzi, C. Elphick, and S. McGehee. 2002. El programa Omora de anillamiento de aves en los bosques subantárticos. Boletín Chileno de Ornitología 9:2-11.

Anderson, C., and R. Rozzi. 2000. Bird assemblages in the southernmost forests in the world: methodological variations for determining species composition. Anales del Instituto de la Patagonia, Serie Ciencias Naturales 28:89-100.

Arroyo, M. T., C. Donoso, R. E. Murúa, E. E. Pisano, R. P. Schlatter, I. A. Serey. 1996. Toward an ecologically sustainable forestry project. Protecting biodiversity and ecosystem processes in the Rio Cóndor project, Tierra del Fuego. DID Universidad de Chile, Santiago, Chile.

Barros, E., and J. Harcha. 2004. La iniciativa de la Reserva de Biosfera Cabo de Hornos: análisis de un desafío para el desarrollo sustentable en la Provincia Antártica Chilena. Pages 27-43 in R. Rozzi, F. Massardo, and C. Anderson, editors. The Cape Horn Biosphere Reserve: a proposal for conservation and tourism to achieve sustainable development at the southern end of the Americas. Ediciones de la Universidad de Magallanes, Punta Arenas, Chile.

Bazzaz, F., G. Ceballos, M. Davis, R. Dirzo, P. R. Ehrlich, T. Eisner, S. Levin, J. H. Lawton, J. Lubchenco, P. A. Matson, H. A. Mooney, P. H. Raven, J. H. Roughgarden, J. Sarukhan, D. J. Tilman, P. Vitousek, B. Walker, D. H. Wall, E. O. Wilson, and G. M. Woodwell. 1998. Ecological science and the human predicament. Science 282:879.

Bowler. P. J. 1993. The Norton history of the environmental sciences. W. W. Norton, New York, New York, USA.

Bradshaw, G. A., and M. Beckoff. 2001. Ecology and social responsibility: the re-embodiment of science. Trends in Ecology and Evolution 16:460-465.

Bridges, T. 1933. Yamana-English dictionary. Manuscript 1870, republished in 1987 by Zaglier y Urruty Publicaciones, Buenos Aires, Argentina.

Clark, T. W. 2001. Developing policy-oriented curricula for conservation biology: professional and leadership education in the public interest. Conservation Biology 15:31.

Darwin C. 1839. The voyage of the Beagle. Everyman's Library, London, UK.

Feinsinger, P., L. Margutti, and R. D. Oviedo. 1997. School yards and nature trails: ecology education outside the university. Trends in Ecology and Evolution 12:115-120.

Goffinet, B., W. Buck, F. Massardo, and R. Rozzi. 2006. The miniature forests of Cape Horn. Ediciones Universidad de Magallanes, Punta Arenas, Chile, in press.

Greenewalt, C. H. 1990. Hummingbirds. Dover, New York, New York, USA.

Gunderson, L. H., C. S. Holling, and S. S. Light. 1995. Barriers broken and bridges built: a synthesis. Pages 489-532 in L. H. Gunderson, C. S. Holling, and S. S. Light, editors. Barriers and bridges to the renewal of ecosystems and institutions. Columbia University Press, New York, New York, USA.

Gusinde, M. 1961. The Yamana: the life and thought of the Water Nomads of Cape Horn. Volumes I-V. New Haven, Connecticut, USA.

Heemskerk, M., K. Wilson, and M. PavaoZuckerman. 2003 Conceptual models as tools for communication across disciplines. Conservation Ecology 7 (3):8. [online] URL: http://www.consecol. org/vol7/iss3/art8.

Holling, C. S. 2004. From complex regions to complex worlds. Ecology and Society 9 (1):

11 [online] URL: http://www.ecologyandsociety.org/ vol9/iss1/art11/main.html.

Hubbard, C., B. Barta, and J. Davis. 2003. Lonely planet Chile and Easter Island. Sixth edition. Lonely Planet, Oakland, California, USA. 
Huntley, B. J., E. Ezcurra, E. R. Fuentes, K. Fujii, P. J. Grubb, W. Haber, J. Harger, M. Holland, S. A. Levin, J. Lubchenco, H. Mooney, I. Noble, V. Neronov, R. Pulliam, P. Ramakrishnan, P. Risser, O. Sala, J. Sarukhan, and W. Sombroek. 1991. Una biosfera sustentable: el imperativo global. Revista Chilena de Historia Natural 64:227-235.

Ippi, S., and N. González. 2004. Arte y ciencia en los bosques en miniatura del Cabo de Hornos. Revista Feria Científica Escolar (UMAG) 4:17-18.

Jax, K., and R. Rozzi. 2004. Ecological theory and values in the determination of conservation goals: examples from temperate regions of Germany, USA, and Chile. Revista Chilena de Historia Natural 77:349-366.

Krüger, O. 2005. Tourism and flagship species in conservation. Biodiversity and Conservation 14:579-60.

Leopold, C. 2004. Living with the land ethic. BioScience 54:149-154.

López-Callejas, M. V., and F. Bozinovic. 1995. Maximum metabolic rate, thermal insulation and aerobic scope in a small-sized Chilean hummingbird (Sephanoides sephanoides). The Auk 112:1034-1036.

Luchenco, J. 1998. Entering the century of the environment: a new social contract for science. Science 279:491-497.

Lubchenco, J., A. M. Olson, L. B. Brubaker, S. R. Carpenter, M. M. Holland, S. P. Hubbell, S. A. Levin, J. A. Macmahon, P A. Matson, J. M. Melillo, H. A. Mooney, C. H. Peterson, H. R. Pulliam, L. A. Real, P. J. Regal, and P. G. Risser. 1991. The sustainable biosphere initiative: an ecological research agenda. Ecology 72:371-412.

Massardo, F., and R. Rozzi. 2004. Etnoornitología yagán y lafkenche en los bosques templados de Sudamérica austral. Ornitología Neotropical 15:395-407.

Massardo F., and R. Rozzi. 2006. The world's southernmost ethnoecology: Yahgan craftsmanship and traditional ecological knowledge. Ediciones Universidad de Magallanes, Punta Arenas, Chile, in press.

McEwan, C., L. Borrero, and A. Prieto. 1997.
Patagonia: natural history, prehistory and ethnography at the uttermost part of the Earth. Princeton University Press, Princeton, New Jersey, USA.

McGehee, S., R. Rozzi, and C. Anderson. 2002. The world's southernmost hummingbird: the Green-backed Firecrown (Sephanoides galeritus) in the Cape Horn Archipelago. NetLines: Hummer Bird Study Group 8 (4):7.

Mittermeier, R.A., C. Mittermeier, P. Robles-Gil, J. Pilgrim, G. Fonseca, T. Brook, and W. Konstant. 2002. Wilderness: Earth's last wild places. CEMEX-Conservation International, Washington, D.C., USA.

Noss, R. F. 1999. Is there a special conservation biology? Ecography 22:113-122.

Oelschlaeger, M., and R. Rozzi. 1998. El nudo gordiano interdisciplinario: un desafío para la sustentabilidad. Ambiente y Desarrollo XIV (3):71-81.

Pandey, S., and M. Wells. 1997. Ecodevelopment planning at India's Great Himalayan National Park for biodiversity conservation and participatory rural development. Biodiversity and Conservation 6:1277-1292.

Pisano, E. 1981. Bosquejo fitogeográfico de FuegoPatagonia. Anales del Instituto de la Patagonia 12 :159-171.

Poblete, M., and A. Salas. 1997. Fonemas yámana. Estructura fonológica de la palabra. Revista de Lingüística Teórica y Aplicada 35:125-133.

Primack, R., R. Rozzi, P. Feinsinger, R. Dirzo, and F. Massardo. 2001. Fundamentos de donservación biológica: perspectivas Latinoamericanas. Fondo de Cultura Económica, Mexico City, Mexico.

Rivas, P., C. Ocampo, and E. Aspillaga. 1999. Poblamiento temprano de los Canales Patagónicos: el núcleo septentrional. Anales del Instituto de la Patagonia 27:221-230.

Rozzi, R. 1999. The reciprocal links between evolutionary-ecological sciences and environmental ethics. BioScience 49(11):911-921.

Rozzi, R. 2002. Biological and cultural 
conservation in the archipelago forest ecosystems of southern Chile. Dissertation. Department of Ecology and Evolutionary Biology, University of Connecticut, Storrs, Connecticut, USA.

Rozzi, R. 2004. Implicaciones éticas de narrativas yaganes y mapuches sobre las aves de los bosques templados de Sudamérica austral. Ornitología Neotropical 15:435-444.

Rozzi, R. 2005. El Parque Etnobotánico Omora: un espacio físico y conceptual para integrar la diversidad biocultural y el bienestar ecosocial en la Provincia Antártica Chilena. In D. Tecklin, editor. Bosque nativo y comunidades locales del sur de Chile. Editorial Universitaria, Santiago, Chile, in press.

Rozzi, R., and P. Feinsinger. 2001. Desafíos para la conservación biológica en Latinoamérica. Pages 661-688 in R. Primack, R. Rozzi, P. Feinsinger, R. Dirzo, and F. Massardo, editors. Fundamentos de conservación biológica: perspectivas Latinoamericanas. Fondo de Cultura Económica, Mexico City, Mexico.

Rozzi, R., and K. Heidinger. 2006. The route of Darwin through the Cape Horn Archipelago. Ediciones Universidad de Magallanes, Punta Arenas, Chile, in press.

Rozzi, R., P. Feinsinger, and R. Riveros. 1997. La enseñanza de la ecología en el entorno cotidiano. Ministerio de Educación de Chile, Santiago, Chile.

Rozzi, R., E. Hargrove, J. J. Armesto, S. T. A. Pickett, and J. Silander. 1998. "Natural drift" as a post-modern metaphor. Revista Chilena de Historia Natural 71:9-21.

Rozzi, R., J. Silander, J. J. Armesto, P. Feinsinger, and F. Massardo. 2000. Three levels of integrating ecology with the conservation of South American temperate forests: the initiative of the Institute of Ecological Research Chiloé, Chile. Biodiversity and Conservation 9:1199-1217.

Rozzi, R., F. Massardo J. Silander, Jr., C. Anderson, and A. Marin. 2003a. Conservación biocultural y ética ambiental en el extremo austral de América: oportunidades y dificultades para el bienestar ecosocial. Pages 51-85 in E. Figueroa and J. Simonetti, editors. Biodiversidad y Globalización. Editorial Universitaria, Santiago, Chile.
Rozzi, R., F. Massardo, C. Anderson, S. McGehee, G. Clark, G. Egli, E. Ramilo, U. Calderón, C. Calderón, L. Aillapan, and C. Zárraga. 2003b. Multi-ethnic bird guide of the austral forests of South America. Editorial Fantástico Sur-Universidad de Magallanes, Punta Arenas, Chile.

Rozzi, R., F. Massardo, J. Silander Jr., C. Anderson, O. Dollenz, and A. Marin. 2003c. El Parque Etnobotánico Omora: una alianza públicoprivada para la conservación biocultural en el confín del mundo. Ambiente y Desarrollo XIX(1):45-71.

Rozzi, R., F. Massardo, and C.Anderson, editors. 2004. The Cape Horn Biosphere Reserve: a proposal for conservation and tourism to achieve sustainable development at the southern end of the Americas. Ediciones Universidad de Magallanes, Punta Arenas, Chile.

Rozzi, R., F. Massardo, A. Mansilla, C.Anderson, and J. Plana. 2006a. The virgin landscapes of the Cape Horn Biosphere Reserve. Ediciones Universidad de Magallanes, Punta Arenas, Chile, in press.

Rozzi, R., F. Massardo, C. Anderson, A. Berghoefer, A. Mansilla, M. Mansilla, J. Plana, U. Berghoefer, E. Barros, and P. Araya. $2006 b$. The Cape Horn Biosphere Reserve. Ediciones de la Universidad de Magallanes, Punta Arenas, Chile.

Shaw, A. J., and B. Goffinet. 2000. Molecular evidence of reticulate evolution in the peatmosses (Sphagnum L.), including S. ehyalinum n. sp. The Bryologist 103:357-374.

Silander, J., Jr. 2000. Temperate forests: plant species biodiversity and conservation. Pages 607-626 in S. A. Levin, editor. Encyclopedia of Biodiversity. Academic Press, New York, New York, USA.

Simonetti, J. A., M. T. K. Arroyo, A. Spotorno, and E. C. Lozada, editors. 1995. Diversidad Biológica de Chile. CONICYT, Santiago, Chile.

Smith, D. 2004. Issues and trends in higher education biology fieldwork. Journal of Biological Education 39:6-10.

UNESCO. 2000. Solving the puzzle: the ecosystem 
approach and biosphere reserves. http://portal.unes co.org/education/en/ev.php-URL ID $=21951 \&$ URL DO= DO TOPIC\&URL SECTION=201.html.

Vitousek, P. 1994. Beyond global warming: ecology and global change. Ecology 75:1861-1876.

Walpole, M. J., and N. Leader-Williams. 2002. The role of ecotourism in conservation: panacea or Pandora's box? Biodiversity and Conservation 11:543-547.

Zárraga, C., F. Massardo, and R. Rozzi. 2006. Hen Harmameuti Hen Maruti Intein: diccionario infantil Yagán. FONDART, Ediciones Universidad de Magallanes, Punta Arenas, Chile, in press. 


\section{Appendix 1. Appendix 1}

Please click here to download file 'appendix1.pdf'. 


\section{Appendix 2. Appendix 2}

\section{Please click here to download file 'appendix2.pdf'.}


Appendix 3. Appendix 3

Please click here to download file 'appendix3.ppt'. 